\title{
PRODUKSI DAN PENERAPAN TEKNOLOGI HAYATI (BIOKOMPOS, BIOAKTIVATOR DAN BIBIT UNGGUL BAWANG MERAH) PADA BUDIDAYA TANAMAN BAWANG MERAH
}

\author{
I Made Sudantha $^{1 *)}$, Ruth Stella Petrunella Thei ${ }^{1)}$, Irfan Jayadi ${ }^{2)}$ \\ 1) Fakultas Pertanian Universitas Mataram \\ ${ }^{2)}$ Fakultas MIPA Universitas Nahdlatul Wathan Mataram \\ *Korespondensi: imade_sudantha@yahoo.co.id
}

\begin{abstract}
ABSTRAK
Tujuan IbM ini adalah petani dapat membuat secara mandiri bioaktivator dan biokompos dengan teknologi fermentasi menggunakan jamur saprofit $T$. harzianum isolat SAPRO-07 dan endofit T. koningii isolat ENDO-02. Selain itu petani dapat mengaplikasikan bioaktivator dan biokompos yang telah dibuat untuk tanaman bawang merah menggunakan bibit unggul. Metode kegiatan yang digunakan dalam program IbM dilaksanakan dengan metode pendidikan dan pelatihan (Diklat) yang dilanjutkan dengan kerja praktek di lapang dan kaji tindak partisipatif aktif (partisipatory action research) sejak persiapan hingga evaluasi. Pemberian materi menggunakan metode penyuluhan melalui ceramah dan diskusi yang dilakukan di Kelompok Tani "Senteluk II" dan "Aiq Genit" Desa Senteluk Kecamatan Batulayar Kabupaten Lombok Barat. Berdasarkan hasil yang telah dilaksanakan maka dapat ditarik beberapa kesimpulan sebagai berikut: (1). Pengetahuan anggota kelompok tani ternak "Senteluk II" menjadi meningkat dalam memahamami teknik pembuatan biokompos dan bioaktivator, dan anggota Kelompok Tani "Aiq Genit" menjadi meningkat dalam memahami teknik aplikasi biokompos dan bioaktivator pada budidaya tanaman bawang merah. (2). Keterampilan anggota kelompok tani ternak "Senteluk II" meningkat dalam pembuatan biokompos dan bioaktivator dan keterampilan anggota Kelompok Tani "Aiq genit" meningkat dalam mengaplikasikan biokompos dan bioaktivator pada budidaya tanaman bawang merah. Sebagai indikatornya adalah peserta pelatihan mampu membuat biokompos dan bioaktivator serta aplikasi biokompos dan bioaktivator pada tanaman bawang merah dilakukan secara mandiri. (3). Hasil biokompos yang diperoleh rata-rata sebanyak 4,0 ton dari target sebanyak 2,0 ton, dan hasil rata-rata bioaktivator rata-rata sebanyak $20 \mathrm{~kg}$ dari target $10 \mathrm{~kg}$. (4). Hasil bawang merah yang diperoleh rata-rata sebanyak 14 ton/ha dari target sebanyak 12 ton/ha.
\end{abstract}

Kata kunci: Biokompos, bioaktivator, jamur Trichoderma, bawang merah

\section{PENDAHULUAN}

Kelompok Tani "Senteluk II" adalah salah satu kelompok tani yang bergerak dibidang ternak sapi. Kelompok tani diketuai oleh Saufi H. dan Sekretaris Burhanudin, dan jumlah anggota 50 orang dengan jumlah ternak sapi sebanyak 70 ekor. Persoalan yang dihadapi oleh Mitra I ini adalah : a) Kurang pengetahuan tentang manfaat kotoran sapi sebagai pupuk oragnik sehingga kotoran sapi dibiarkan bertumpuk yang menyebabkan pencemaran lingkungan; b) Kurang pengetahuan dan keterampilan dalam pengelolaan limbah ternak sapi menjadi bioaktivator dan 
biokompos; c) Kurang pengetahuan tentang keberadaan kandang kolektif dan kelembagaan kelompok tani yang lemah dan kerjasama anggota kelompok yang kurang, sehingga kegiatan usaha kelompok belum optimal.

Kelompok Tani "Senteluk II" ini memiliki 70 ekor sapi dan dalam satu hari satu ekor sapi dewasa menghasilkan $20 \mathrm{~kg}$ kotoran sapi, sehingga dalam satu hari kelompok ternak ini memiliki $1.400 \mathrm{~kg}$ kotoran sapi dan dalam satu bulan memiliki $42.000 \mathrm{~kg}$ (42 ton). Karena kurangnya pengetahuan dan keterampilan anggota kelompok tani ini menyebabkan kotoran sapi ini dibiarkan menumpuk begitu saja di kandang, sehingga menimbulkan pencemaran lingkungan dan emisi GRK. Padahal kotoran sapi yang merupakan limbah ini berpotensi utuk dikembangkan menjadi biokompos. Apabila kotoran sapi ini diproses menjadi biokompos maka akan diperoleh biokompos sebanyak 33\% dari berat basahnya. Dengan demikian akan dihasilkan biokompos sebanyak 462 $\mathrm{kg} /$ hari. Jika harga biokompos Rp. 1.500/kg maka potensi penghasilan adalah $\mathrm{Rp}$ 693.000/ hari dan dalam satu bulan rata-rata penghasilan dari biokompos adalah $\mathrm{Rp}$ 20.790.000,-

Permasalahan yang terjadi selama ini adalah kelompok ternak ini belum memanfaatkan secara maksimal kotoran sapi ini, selain itu apabila kotoran sapi ini tidak dikelola dengan baik maka akan menimbulkan bau dan ketika musim hujan tiba kotoran ini hanyut bersama air hujan dan menimbulkan pencemaran lingkungan, selain itu limbah ternak merupakan kontributor GRK yang signifikan.

Sejauh ini kelompok tani ini belum diberdayakan dan belum mengetahui inovasi dan teknologi pengelolaan limbah tersebut serta pemanfaatannya dalam pengembangan produk unggulan seperti tanaman bawang merah.
Kelompok Tani “Aiq Genit” merupakan salah satu kelompok tani yang bergerak dalam bidang budidaya bawang merah. Kelompok tani ini diketuai oleh $\mathrm{H}$. Abdul Muas dan Sekretaris Fajri, dan jumlah anggota 102 orang dengan luas lahan sawah $20 \mathrm{Ha}$. Persoalan yang dihadapi oleh Mitra II ini adalah : a) Produksi benih/ bibit unggul dan bermutu belum optimal; b) Hasil bawang merah belum optimal (ratarata 6 ton/ha); c) Tanah kurang subur; dan d) Serangan jamur Fusarium penyebab penyakit layu.

Berdasarkan permasalahan yang dihadapi oleh Mitra I dan Mitra II maka dibuat perumusan dan kesepakatan bersama antara Tim Pelaksana IbM dengan Mitra I dan Mitra II sebagai berikut:

a. Kesepakatan dengan Kelompok Tani "Senteluk II" (Mitra I)

Perumusan dan kesepakatan antara Tim Pelaksana dengan Kelompok Tani "Senteluk II" adalah memproduksi kotoran sapi menjadi biokompos yang bermanfaat untuk menambah kesuburan tanah yang akan ditanami bawang merah.

Biokompos atau kompos bioaktif adalah kompos yang diproduksi dengan bantuan mikroba lignoselulolitik unggul yang tetap bertahan di dalam kompos dan berperan sebagai agensia hayati pengendali penyakit tanaman. Teknologi yang akan diterapkan dalam pembuatan biokompos ini adalah teknologi fermentasi Biotrichon yaitu proses fermentasi biokompos yang dilakukan secara buatan dengan bantuan inokulasi mikroorganisme fermentasi dan dalam waktu 2-3 minggu limbah organik dapat menjadi biokompos (Sudantha, 2011).

Bioaktivator merupakan inokulan pemacu pertumbuhan dan pembungaan tanaman. Penggunaan bioaktivator (mengandung jamur saprofit $T$. harzainum isolat SAPRO-07 dan jamur endofit $T$. koningii isolat ENDO-02) pada tanaman kedelai dapat memacu pertumbuhan dan 
pembungaan di rumah kaca. Jamur $T$. polysporum isolat ENDO-04 dan $T$. harzianum isolat SAPRO-07 yang dibiakan pada berbagai substrat dapat diformulasi dalam bentuk cair, tablet dan granula/butiran (Sudantha dan Suwardji, 2015).

Peran biokompos hasil fermentasi jamur Trichoderma spp. Adalah : 1) Sebagai sumber unsur hara bagi tanaman dan sumber energi bagi organisme tanah; 2) Memperbaiki sifat-sifat tanah, memperbesar daya ikat tanah berpasir, memperbaiki struktur tanah berlempung sehingga lebih ringan, mempertinggi kemampuan tanah mengikat air, memperbaiki drainase dan tata udara pada tanah berat sehingga suhu tanah lebih stabil; 3) Membantu tanaman tumbuh dan berkembang lebih baik; 4) Sebagai substrat untuk meningkatkan aktivitas mikrobia antagonis; 5) Untuk mencegah patogen tular tanah (Sudantha, 2010).

b. Kesepakatan dengan Kelompok Tani "Aiq Genit" (Mitra II)

Kelompok Tani "Aiq Genit" untuk memanfaatkan biokompos yang dihasilkan oleh Kelompok Tani Terpadu "Senteluk II" dengan tujuan untuk meningkatkan kesuburan tanah sekaligus menjaga keseimbangan ekosistem dalam tanah, selain itu untuk meningkatkan kesehatan tanaman, sehingga terhidar dari serangan penyakit layu Fusarium. Dengan demikian penerapan budidaya tanaman bawang merah dengan teknologi hayati dapat meningkatkan kuantitas dan kualitas hasil bawang merah.

Sudantha (2015) melaporkan bahwa bioaktivator ( $5 \mathrm{~g} /$ tanaman setara dengan 1,2 ton/ha) dan biokompos (15 g/tanaman setara dengan 3,75 ton/ha) yang diaplikasikan pada tanaman bawang merah dapat menekan penyakit layu Fusarium secara total. Suwardji dan Sudantha (2016) melaporkan bahwa aplikasi bioaktivator dan biokompos hasil fermentasi jamur saprofit
T. harzianum isolat SAPRO-07 dan jamur endofit T. koningii isolat ENDO-02 pada tanaman bawang merah dapat mengendalikan penyakit layu Fusarium dan meningkatkan produktivitas hasil mencapai 12,5 ton/ha. Selanjutnya dilaporkan pula bahwa penggunaan varietas Ampenan dan Thailand dapat meningkatkan produktivitas hasil apabila diberikan bioaktivator dan biokompos.

Bertolak dari uraian di atas, maka dilakukan IbM dengan judul: "Produksi dan Penerapan Teknologi Hayati (Biokompos, Bioaktivator dan Bibit Unggul Bawang Merah) Pada Budidaya Tanaman Bawang Merah.

Tujuan dari IbM adalah:

1. Petani dapat membuat secara mandiri biokompos dan bioaktivator dengan teknologi fermentasi menggunakan jamur saprofit $T$. harzianum isolat SAPRO-07 dan jamur endofit T. koningii isolat ENDO-02.

2. Petani dapat mengaplikasikan biokompos dan bioaktivator yang telah dibuat untuk tanaman bawang merah yang menggunakan bibit unggul dalam upaya meningkatkan kesehatan, pertumbuhan dan hasil bawang merah.

\section{METODE KEGIATAN}

Kegiatan program IbM ini dilkasanakan dengan Metode Pendidikan dan Pelatihan (Diklat) yang dilanjutkan dengan kerja praktek di lapang dan kaji tindak partisipatif aktif (partisipatory action research) di lapang secara aktif sejak persiapan hingga evaluasi. Tahapan-tahapan pelatihan dan kaji tindak yang diterapkan sebagai berikut:

1. Pemberian teori tentang teknik pembuatan biokompos dan bioaktivator serta aplikasinya pada budidaya tanaman bawang merah yang dilaksanakan di Kelompok Tani 
"Senteluk II" dan "Aiq Genit" Desa Senteluk Kecamatan Batulayar Kabupaten Lombok Barat (masingmasing 5 orang anggota/ kelompok).

2. Praktek lapang tentang teknik pembuatan biokompos dan bioaktivator serta aplikasinya pada budidaya tanaman bawang merah yang menggunakan bibit unggul.

\section{Metode Pembuatan Biokompos yang Diterapkan di kelompok Tani "Senteluk II}

1. Pengumpulan kotoran sapi dari kandang kolektif

2. Pemotongan jerami padi sebagai bahan biokompos secara manual atau menggunakan mesin pemotong

3. Pembuatan biokompos dengan teknologi fermentasi

4. Pengemasan biokompos dalam kantong plastik ukuran $10 \mathrm{~kg}$ atau $5 \mathrm{~kg}$.

\section{Metode Budidaya Bawang Merah yang Diterapkan di Kelompok Tani "Aiq Genit.}

Rangkaian kegiatan terdiri dari pembersihan lahan, pengolahan tanah, pemupukan dasar, pembuatan bedengan, penanaman, pemeliharaan dan panen sebagai berikut:

1. Pembersihan Lahan dan Mengolah Tanah

2. Penanaman

3. Penutupan dengan Mulsa Jerami dan Pengairan

4. Pemeliharaan: Pengendalian Hama dan Penyakit dan Penyiraman

5. Panen

Evaluasi untuk mengukur keberhasilan kegiatan $\mathrm{I}_{\mathrm{b}} \mathrm{M}$ Kelompok Tani "Senteluk II" sebagai Mitra I dan Kelompok Tani “Aiq Genit" sebagai Mitra II ini dilakukan terhadap :

1. Respon peserta pada saat penyampaian

2. Respon peserta pada saat pelaksanaan praktek pembuatan biokompos dan bioaktivator serta aplikasinya pada budidaya tanaman bawang merah menggunakan bibit unggul.

3. Target produksi biokompos dan bioaktivator

4. Target produktivitas hasil bawang merah

5. Analisis ekonomis dan kelayakan pembuatan biokompos dan bioaktivator serta budidaya tanaman bawang merah.

\section{HASIL DAN PEMBAHASAN}

\section{Pembuatan Bioaktivator}

Pembuatan bioaktivator dilakukan oleh Tim Pelaksana dilaksanakan mulai tanggal 14 Mei s.d. 30 Mei 2017 di Laboratorium Proteksi Fakultas Pertanian Universitas Mataram. Tahapan-tahapan pembuatan bioaktivator sebagai berikut:

1. Pemurnian dan Perbanyakan Jamur Trichoderma spp.

Pemurnian jamur T. koningii isolat Endo-02 dan T. harzianum isolat Sapro-07 pada medium PDA dilakukan oleh Tim Pelaksana dilanjutkan dengan pembiakan massal dan pemanenan spora yang digunakan sebagai larutan induk dalam pembuatan bioaktivator.

2. Pembuatan Larutan Induk dan Formulasi Pembuatan larutan induk spora jamur $T$. koningii isolat Endo-02 dan T. harzianum isolat Sapro-07 (Gambar 1) dengan cara biakan jamur dimasukkan kedalam satu liter air kemudian diaduk sampai spora jamur terlepas dari PDA, setelah itu disaring untuk mendapatkan larutan induk. Selanjutnya dilakukan formulasi bioaktivator (Gambar 2) dengan cara sebagai berikut: Ketiga formulasi Bioaktivator ini dibuat dengan bahan dasar substrat/ekstrak daun kopi dan tanah liat/clay. Formulasi tablet dibuat dengan cara mencampur substrat daun kopi dengan tanah liat/clay steril masing-masing berukuran $2 \mathrm{~mm}$ dengan perbandingan 3:1 (v/v), kemudian diinokulasi dengan 
suspensi biomasa konidia jamur T. koningii isolat Endo-02 atau T. harzianum isolat SAPRO-07, dimasukkan ke dalam alat pembuat tablet (satu tablet berdiameter 10,0 $\mathrm{mm}$ dan berat $50,0 \mathrm{mg}$ ). Formulasi cairan dibuat dengan ekstrak bahan $1 \%$ (campuran ekstrak daun kopi dan WA dengan perbandingan 1:9 (v/v) diinokulasi dengan suspensi biomassa konidia jamur $T$. koningii isolat Endo-02 atau T. harzianum isolat SAPRO-07 secara mandiri atau campuran, diinkubasikan dalam alat fermintor. Formulasi granula/butiran dibuat dengan mencampur substrat daun kopi dengan tanah liat/clay steril masingmasing berukuran $2 \mathrm{~mm}$ dengan perbandingan 10:1 (v/v), kemudian diinokulasi dengan suspensi biomasa konidia jamur $T$. koningii isolat Endo-02 atau T. harzianum isolat SAPRO-07 secara mandiri atau campuran, dimasukkan ke dalam alat pembuat butiran.
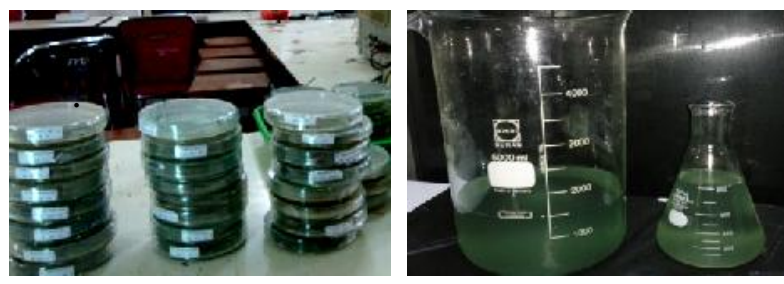

Gambar 1. Pembuatan larutan induk spora jamur T. koningii isolat Endo02 dan $T$. harzianum isolat Sapro-07.
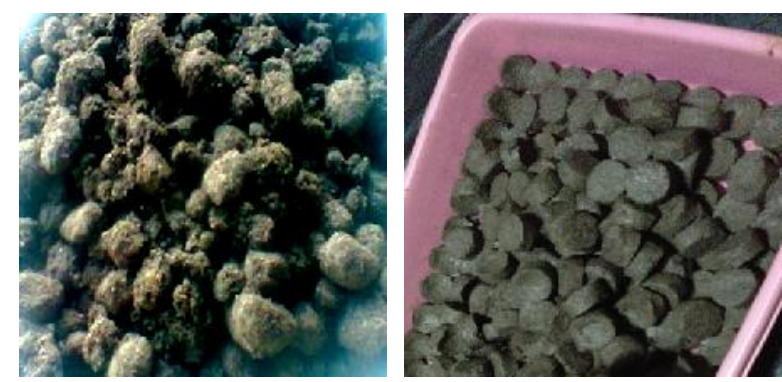

Gambar 2. Bioaktivator yang mengandung jamur T. koningii isolat Endo02 dan $T$. harzianum isolat Sapro-07 diformulasikan dalam bentuk butiran dan tablet

\section{Pemberian Materi Pelatihan}

Pemberian materi pelatihan tentang teknik pembuatan biokompos dan bioaktivator serta teknik aplikasinya pada budidaya tanaman bawang merah dilaksanakan selama satu hari, yaitu: Hari Sabtu, 24 Juni 2017. Pemberian materi pelatihan dilaksanakan di Kantor Desa Senteluk Kecamatan Batu layar Kabupaten Lombok Barat yang dihadiri oleh anggota kelompok tani "Senteluk II" dan "Aiq Genit" sebanyak 15 orang petani. Kegiatan pada saat pemberian materi disajikan pada Gambar 3.

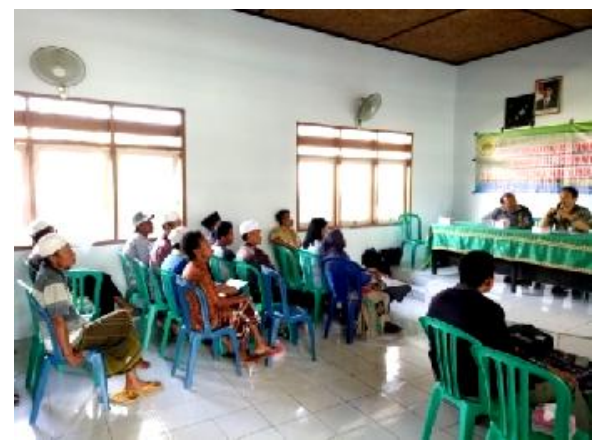

Gambar 3. Peyampaian materi

\section{Pendampingan Praktek Lapang Pembuatan Biokompos dan Bioaktivator}

Pendampingan praktek lapang pembuatan biokompos dan bioaktivator dengan teknologi fermentasi menggunakan jamur T. koningii isolat Endo-02 dan jamur T. harzianum isolat Sapro-07 dilaksanakan mulai 30 Juni s.d. 30 Juli 2017 di Rumah Kompos Kelompok Tani "Senteluk II" di Desa Senteluk Kecamatan Batu Layar Kabupaten Lombok Barat. Tahapantahapan pendampingan praktek lapang pembuatan biokompos sebagai berikut:

1. Pembuatan Rumah Kompos dan Pengumpulan Kotoran Ternak

Peserta pelatihan melakukan pembuatan rumah kompos dan pengumpulan kotoran ternak dari kandang kolektif setiap pagi dan penjemuran kotoran ternak sebanyak 4 ton (Gambar 4). 

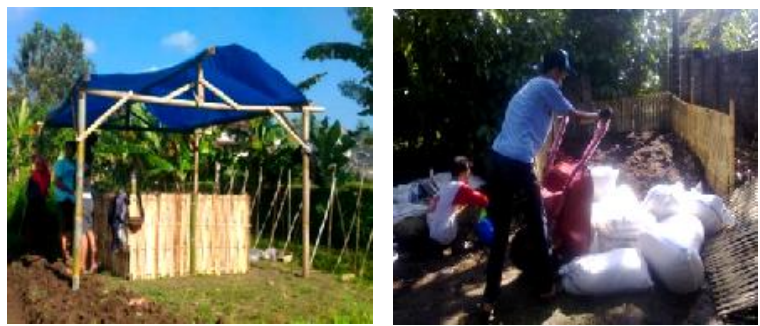

Gambar 4. Pada pembuatan biokompos diawali dengan pembuatan rumah kompos dan pengumpulan kotoran ternak sapi oleh peserta pelatihan.

2. Pembuatan Larutan Bioaktivator sebagai Pengurai Biokompos

Untuk mempercepat

proses pengomposan, peserta pelatihan membuatan larutan bioaktivator yang mengandung jamur T. koningii isolat Endo-02 dan jamur T. harzianum isolat Sapro-07 sebagai pengurai biokompos. Larutan bioaktivator sebanyak 1 liter diencerkan dengan penambahan 10 liter air untuk pembuatan 4 ton biokompos (Gambar 5).
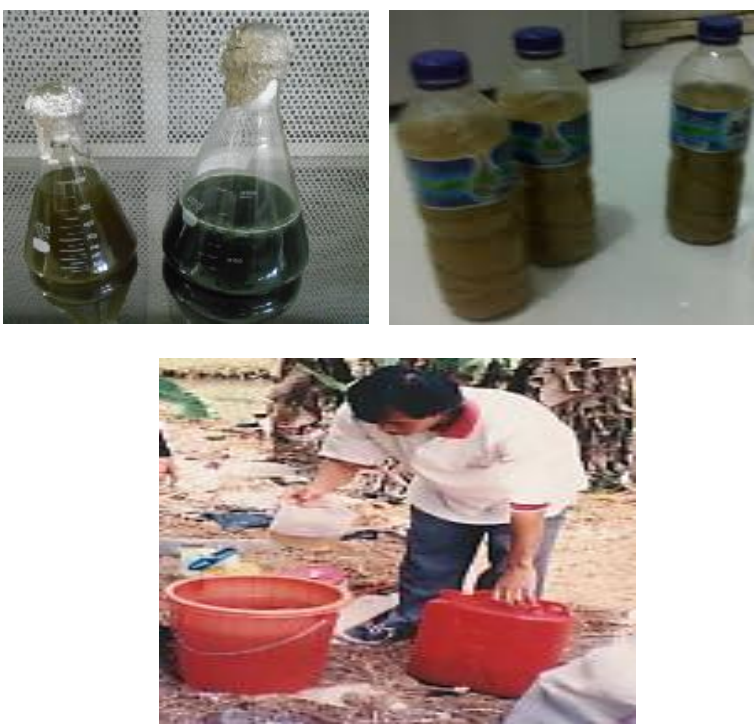

Gambar 5. Pembuatan larutan bioaktivator yang mengandung jamur $T$. koningii isolat Endo-02 dan jamur T. harzianum isolat Sapro07 sebagai pengurai biokompos
3. Aplikasi Larutan Bioaktivator pada Pembuatan Biokompos

Larutan bioaktivator yang encer selanjutnya disiramkan dengan gembor pada bahan biokompos yang telah tumpuk dalam bak fermentasi yang terbuat dari pagar bambu yang diberi alas terpal plastik (Gambar 6).

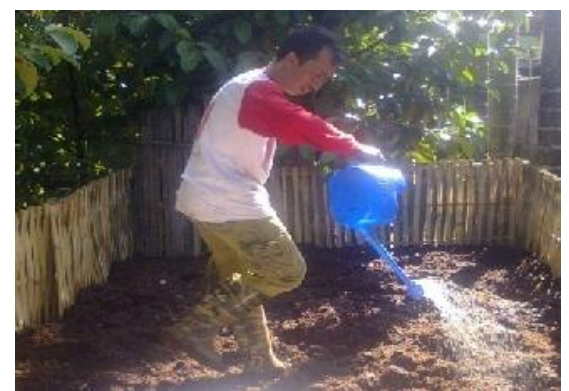

Gambar 6. Larutan bioaktivator yang mengandung jamur $T$. koningii isolat Endo-02 dan jamur $T$. harzianum isolat Sapro-07 disiramkan secara merata pada bahan biokompos

a. Proses Fermentasi Pada Pembuatan Biokompos

Setelah larutan bioaktivator disiramkan secara merata pada bahan biokompos selanjutnya dilakukan fermentasi dengan cara menutup tumpukan bahan biokompos secara rapat (kondisi an-aerob) dengan terpal plastik dan selanjutnya dibuka seminggu sekali untuk pembalikan bahan biokompos dan penyiraman kembali dengan larutan bioativator.

b. Analisis dan Pelebelan Biokompos

Setelah dilakukan pembalikan sebanyak dua kali maka biokompos telah matang dengan ciri-ciri (analisis laboratorium): biokompos berwarna hitam, biokompos tidak berbau, pH 6,0; C-organik 1,52; KTK $17,98 \mathrm{cmo} \mathrm{kg}^{-1}$; $\mathrm{C} / \mathrm{N}$ rasio 12,5 ; populasi jamur Trichoderma 45 x 10 propagul/g biokompos, bebas patogen tular tanah (Gambar 7). Selanjutnya dilakukan pengemasan dalam kantong plastik $5 \mathrm{~kg}$ dan $10 \mathrm{~kg}$, dan rekomendasi untuk budidaya 
tanaman bawang merah sebanyak 4 ton/ha. Menurut Sudantha (2015) bahwa biokompos hasil fermentasi jamur Trichoderma spp. dapat berfungsi untuk: (1) sumber unsur hara bagi tanaman dan sumber energi bagi organisme tanah, (2) memperbaiki sifat-sifat tanah, memperbesar daya ikat tanah berpasir, memperbaiki struktur tanah berlempung, (3) membantu tanaman tumbuh dan berkembang lebih baik, (4) substrat untuk meningkatkan aktivitas mikrobia antagonis, (5) untuk mencegah patogen tular tanah.

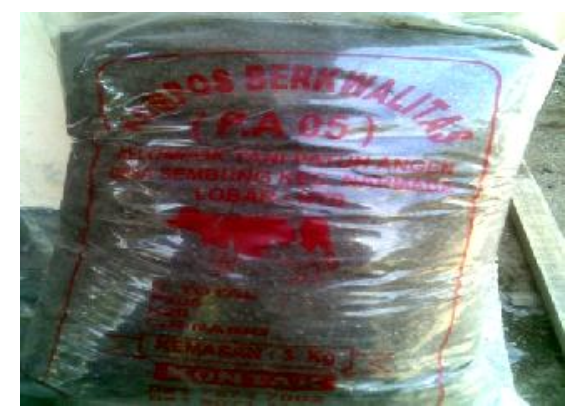

Deskripsi:

Bahan biokompos dari kotoran sapi:

- $\mathrm{pH} 6,0$

- C-organik 1,52

- $\mathrm{KTK} 17,98 \mathrm{cmol} \mathrm{kg}^{-1}$

- $\mathrm{C} / \mathrm{N}$ rasio 12,5

- Populasi Trichoderma spp. 45 x 10 propagul/g biokompos

- Bebas dari patogen tular tanah

- Rekomendasi aplikasi 4 ton/ha untuk tanaman bawang merah

Gambar 7. Biokompos yang telah matang, selanjutnya dikemas dalam wadah kantung plastik $5 \mathrm{~kg}$ dan $10 \mathrm{~kg}$.

Target produksi biokompos pada Kelompok Tani Ternak "Senteluk II" yaitu sebanyak 2,0 ton, namun realisasi produksi biokompos oleh peserta pelatihan sebanyak 4,0 ton dan produksi biokompos ini masih dapat dikembangkan hingga 12 ton (Tabel $1)$.

Tabel 1. Target, realisasi dan potensi pengembangan biokompos di Kelompok Tani Ternak "Senteluk II'

\begin{tabular}{clc}
\hline No. & Pembuatan Biokompos & $\begin{array}{c}\text { Produksi } \\
\text { (ton) }\end{array}$ \\
\hline 1. & Target & 2,0 \\
2. & Realisasi & 4,0 \\
3. & Potensi Pengembangan & 12,0 \\
\hline
\end{tabular}

\section{Pendampingan Praktek lapang Aplikasi Biokompos dan Bioaktivator pada Budidaya Tanaman Bawang Merah}

Pendampingan Praktek lapang aplikasi biokompos pada budidaya tanaman bawang merah dilaksanakan mulai 1 Agustus s.d. 15 Oktober 2017 di lahan Kelompok Tani "Aiq Genit" di Desa Senteluk Kecamatan Batu Layar Kabupaten Lombok Barat. Tahapan-tahapan pendampingan praktek aplikasi biokompos pada budidaya tanaman bawang merah sebagai berikut :

1. Pengolahan Tanah

Pengolahan tanah dilakukan dua minggu sebelum tanam bawang merah dengan cara dibajak dan digaru, setelah itu dibuat saluran untuk memasukan dan membuang air (Gambar 8 dan 9).
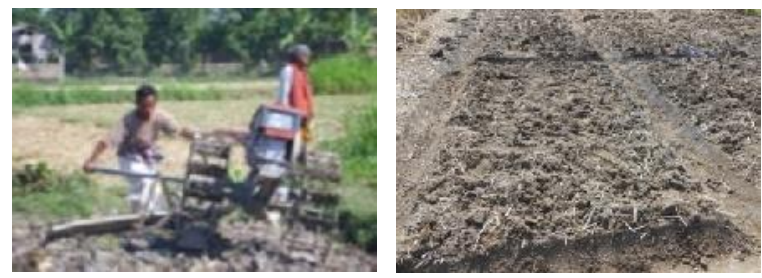

Gambar 8. Pengolahan tanah dilakukan dua minggu sebelum aplikasi biokompos

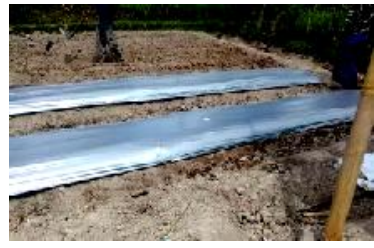

Gambar 9. Pembuatan pemasangan

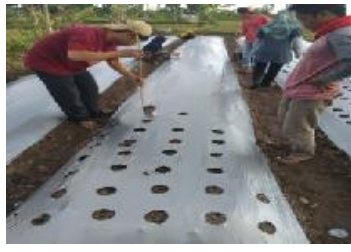

petak-petak dan dan pelubangan 
mulsa plastik untuk budidaya tanaman bawang merah.

\section{Aplikasi Biokompos}

Aplikasi biokompos dilakukan setelah pengolahan tanah dengan cara mencampur biokompos pada lubang tanam sebanyak $15 \mathrm{~g} /$ lubang tanam atau setara dengan 4 ton/ha.

3. Penanaman

Penanaman bibit bawang merah varietas Keta Monca Bima dan Vietnam dilakukan dengan cara ditugal pada lubang tanam dengan jarak tanam $20 \times 20 \mathrm{~cm}^{2}$.

\section{Pengamatan Pertumbuhan Bawang}

Merah

Pengamatan pertumbuhan pada fase vegetatif dilakukan mulai umur dua minggu setelah tanam sampai pada fase vegetatif maksimum umur 5 minggu setelah tanam. Pengamatan pertumbuhan pada fase generatif dilakukan pada saat pembentukan anakan atau umbi bawang merah (Gambar $10)$.
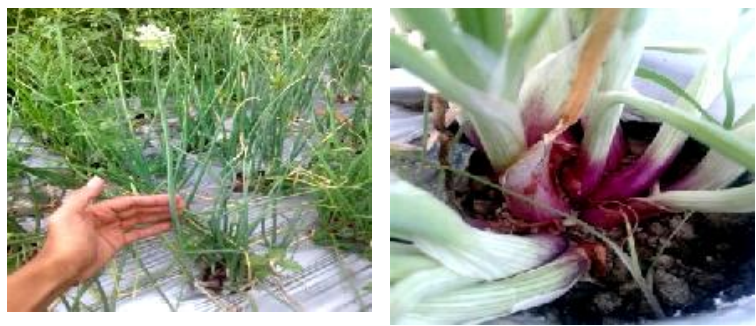

Gambar 10. Pengamatan pertumbuhan tanaman bawang merah

\section{Panen bawang merah}

Panen bawang merah dilakukan setelah tanaman bawang merah berumur 75 hari yang dicirikan dengan warna daun mulai menguning dan pembesaran umbi maksimum (Gambar 11).

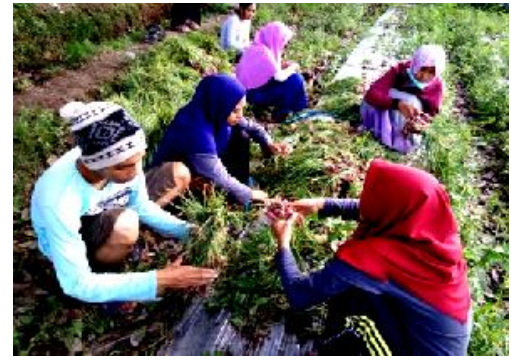

Gambar 11. Panen bawang merah

Target dan realisasi serta potensi pengembangan tanaman bawah merah di kelompok tani "Aiq Genit " dapat dilihat pada Tabel 2.

Tabel 2. Target, Realisasi dan Potensi Pengembangan Tanaman Bawang Merah di Kelompok Tani "Aiq Genit"

\begin{tabular}{llcc}
\hline & \multicolumn{3}{c}{ Busil/ha (ton) } \\
No. & $\begin{array}{c}\text { Tanaman } \\
\text { Bawang Merah }\end{array}$ & $\begin{array}{c}\text { Varietas } \\
\text { Keta } \\
\text { Monca } \\
\text { Bima }\end{array}$ & $\begin{array}{c}\text { Varietas } \\
\text { Vietnam }\end{array}$ \\
\hline 1. & Target & 12,0 & 12,0 \\
2. & Realisasi & 14,0 & 14,0 \\
3. & Potensi & 15,0 & 15,0 \\
& Pengembangan & & \\
\hline
\end{tabular}

\section{KESIMPULAN DAN SARAN}

Berdasarkan hasil kegiatan IbM yang telah dilaksanakan maka dapat ditarik beberapa kesimpulan sebagai berikut:

1. Pengetahuan anggota kelompok tani "Senteluk II" dan "Aiq Genit" menjadi meningkat dalam memahamami teknik pembuatan biokompos dan bioaktivator, dan anggota Kelompok Tani "Aiq Genit" menjadi meningkat dalam memahami teknik aplikasi biokompos dan bioaktivator pada budidaya tanaman bawang merah.

2. Keterampilan anggota kelompok tani ternak "Senteluk II" meningkat dalam pembuatan biokompos dan bioaktivator 
dan keterampilan anggota Kelompok Tani "Aiq genit" meningkat dalam mengaplikasikan biokompos dan bioaktivator pada budidaya tanaman bawang merah. Sebagai indikatornya adalah peserta pelatihan mampu membuat biokompos dan bioaktivator serta aplikasi biokompos dan bioaktivator pada tanaman bawang merah dialkukan secara mandiri.

3. Hasil biokompos yang diperoleh ratarata sebanyak 4,0 ton dari target sebanyak 2,0 ton, dan hasil rata-rata bioaktivator rata-rata sebanyak $20 \mathrm{~kg}$ dari target $10 \mathrm{~kg}$.

4. Hasil bawang merah yang diperoleh rata-rata sebanyak 14,00 ton/ha dari target sebanyak 12,0 ton/ha.

Berdasarkan hasil kegiatan yang telah dilaksanakan, maka dapat disarankan halhal sebagai berikut:

1. Perlu dilakukan pembinaan dan evaluasi lapangan secara intensif dan berkesinambungan terhadap Kelompok Tani "Senteluk II" dan "Aiq Genit", sehingga dapat meningkatkan produktivitas usahataninya.

2. Perlu dipertimbangkan pembuatan biokompos secara komersial dalam skala industri rumah tangga untuk meningkatkan pendapatan Kelompok Tani Ternak "Senteluk II" dan "Aiq Genit" dapat mengaplikasikan biokompos pada budidaya tanaman bawang merah di lahan kering sehingga dapat meningkatkan hasil bawang merah.

\section{UCAPAN TERIMA KASIH}

Terima kasih kepada Direktur Riset Pengabdian Kepada Masyarakat Kemenristekdikti yang telah memberikan dukungan dana untuk melaksanakan kegiatan IbM ini.

\section{DAFTAR PUSTAKA}

Sudantha, I. M. 2007. Karakterisasi dan Potensi Jamur Endofit dan Saprofit Antagonistik Sebagai Agens Pengendali Hayati Jamur Fusarium oxysporum f. sp. vanillae Pada Tanaman Vanili di Nusa Tenggara Barat. Disertasi Program Pascasarjana Universitas Brawijaya, Malang. 337 hal.

Sudantha, I.M. 2009. Aplikasi Jamur Trichoderma spp (Isolat ENDO-02 dan 04 serta SAPRO-07 dan 09) Sebagai Biofungisida, Dekomposer, dan Bioaktivator Pertumbuhan dan Pembungaan Tanaman Vanili dan Pengembanngannya pada Tanaman Hortikultura dan Pangan Lainnya di NTB. Laporan Penelitian Hibah Kompetensi DP2M DIKTI, Mataram. 117 hal.

Sudantha, I. M. 2010. Buku Teknologi Tepat Guna: Penerapan Biofungisida dan Biokompos pada Pertanian Organik. Fakultas Pertanian Universitas Mataram, Mataram.

Sudantha, I. M., 2010a. Pengujian beberapa jenis jamur endofit dan saprofit Trichoderma spp. Terhadap penyakit layu fusarium pada tanaman kedelai. Website: http://fp.unram.ac. id/data/2012/04/20-2-3_02-Sudantha Rev-Wangiyana P.pdf. Tanggal: 25 Mei 2012 .

Sudantha, I. M. 2011. Uji Aplikasi Beberapa Jenis Biokompos (hasil fermentasi jamur $T$. koningii isolat Endo-02 dan T. harzianum isolat Sapro07) pada Dua Varietas Kedelai terhadap Penyakit Layu Fusarium dan Hasil Kedelai. Jurnal Agroteksos Vol. 21 No.1, April 2011. 39 - 46. http:// fp.unram.ac.id-agroteksos (Diunduh pada hari Senin tanggal 25 April 2016).

Sudantha, 2015. Pemanfaatan Bioaktivator dan Biokompos untuk Meningkatkan Kesehatan, Kuantitas dan Kualitas Hasil 
Bawang Merah. Laporan Penelitian Mandiri Program Magister Pengelolaan Sumberdaya Lahan Kering Program Pascasarjana Unram.

Sudantha, I. M. dan Suwardji. 2015. The Use of Biocompost and Bioactivator in a Granule Formulation Containing Trichoderma spp. to Enhance Growth and Yield of Soybean in Tropopsament of North Lombok. International Seminar on the Tropical Natural Resources, Mataram, $11^{\text {th }}$ June 2015.

Suwardji dan I. M. Sudantha. 2016. Pemanfaatan Bioaktivator dan Biokompos Hasil Fermentasi Jamur Endofit dan Saprofit Trichoderma spp. untuk Meningkatkan Kesehatan Tanaman, Kualitas dan Kuantitas Umbi Bawang Merah untuk Benih/Bibit dan Konsumsi. Laporan Penelitian Pengembangan Ipteks Direktorat Riset dan Pengabdian Masyarakat Kemenristek dikti. 80 hal. 